\title{
PENGEMBANGAN MULTIMEDIA PEMBELAJARAN BERBASIS CROSS PLATFORM MATA PELAJARAN IPA PADA SISWA KELAS VIII SEMESTER II DI SMP NEGERI 3 MALANG
}

\author{
MULTIMEDIA DEVELOPMENT BASED LEARNING \\ CROSS PLATFORM SUBJECT IPA IN CLASS VIII SEMESTER II \\ IN SMP NEGERI 3 MALANG
}

\author{
Muhammad Malik Prigianata, Sihkabuden, Punaji Setyosari \\ Program Studi Teknologi Pembelajaran, \\ Pascasarjana Universitas Negeri Malang \\ Email: mprigianata@gmail.com
}

\begin{abstract}
Abstrak: Tujuan penelitian dan pengembangan ini adalah menghasilkan produk pengembangan berupa multimedia untuk mengetahui efektivitas penggunaan media dalam proses pembelajaran dan motivasi belajar siswa pada mata pelajaran IPA kelas VIII.3 di SMP Negeri 3 Malang dengan menggunakan pengembangan multimedia pembelajaran berbasis Cross Platform (Dekstop dan mobile) serta untuk mengetahui kelayakan produk pengembangan multimedia pembelajaran. Model pengembangan yang digunakan dalam penelitian ini adalah model Lee \& Owens dengan menggunakan tiga tahapan yaitu (1) Assessment/Analisis; (2) Desain; (3) Pengembangan; (4) Implementasi; (5) Evaluasi. Perolehan hasil uji validasi multimedia Indera pendengaran dan Sistem Sonar meliputi: 1) ahli materi pada aplikasi dekstop 93,3\% dan mobile 94,6\%, 2) ahli desain pada aplikasi dekstop 85,3\% dan mobile 88\%, 3) ahli media pada aplikasi dekstop 97,3\% dan mobile 97,3\%. Keseluruhannya menunjukkan kriteria sangat layak. Hasil tanggapan siswa meliputi: 1) perorangan aplikasi dekstop $84,6 \%$, mobile $83,3 \%$,2) kelompok kecil pada aplikasi dekstop $84,4 \%$, mobile $83,5 \%$, dan 3) kelompok besar pada dekstop 85\%, pada mobile 85,5\%. Keseluruhan review hasil tanggapan siswa menunjukkan kriteria sangat layak. Hasil tanggapan motivasi siswa meliputi: 1) perorangan aplikasi dekstop 86,6\%, mobile 87,3\%, 2) kelompok kecil pada aplikasi dekstop 83,1\%, mobile 83,6\%, dan 3) kelompok besar pada dekstop 84,7\%, pada mobile $85,3 \%$. Keseluruhan menunjukkan multimedia ini sangat baik dalam meningkatkan motivasi belajar siswa. Hasil uji coba lapangan pada siswa memilki rata-rata hasil belajar 87,35 dengan persentase kelulusan $100 \%$, yang menunjukkan sangat efektif dalam proses pembelajaran.
\end{abstract}

Kata Kunci: Pengembangan, Mutimedia, Cross Platform, Motivasi, Hasil Belajar Kognitif, Dekstop, Mobile

\begin{abstract}
The purpose of this research and development is produce teaching material of science based mobile and desktop learning that can be used as instructional supplement in classroom or as individual learning resource. The model of development used in this study is Lee \& Owens model by using three stages: 1) Assessment; 2) Design; 3) Development; 4) Implementation; and 5) Evaluation. The results of the validation and testing of the product of teaching material of Sense of Hearing and Sonar System of Living Organism based crossplatform instructional learning are: 1) material expert to the dekstop is $93,3 \%$, mobile $94,6 \%$. 2) design expert to the dekstop is $85,3 \%$, mobile $88 \%$, and 3) media expert to the desktop 97,3\% and mobile application $97,3 \%$. Review student responses on: 1) individually to the dekstop $84,6 \%$ and mobile $83,3 \%, 2$ ) small groups to the dekstop $83,1 \%$ and mobile $83,5 \%$, and 3 ) on large group to the desktop $85 \%$, and mobile $85,5 \%$. All of them showed very feasible criteria to the desktop and mobile application. The result of student motivation responses on: 1) individually to the dekstop $84,6 \%$ and mobile $87,3 \%, 2$ ) small groups to the dekstop $83,1 \%$ and mobile $83,6 \%$, and 3 ) on large group to the desktop $84,7 \%$, and mobile $85,3 \%$, which showed that this multimedia was very good in improving student learning motivation. The result of field test to the students showed $100 \%$ passing the test that it was very effective in the learning process.
\end{abstract}

Keywords: Development, Multimedia, Cross Platform, Motivation, Cognitiv Learning Outcome, Desktop, Mobile 
Upaya integrasi teknologi dalam kegiatan pembelajaran menjadi solusi pemecahan masalah pembelajaran saat ini yang sangat besar manfaatnya, meskipun tetap perlu memperhatikan subjek yang dapat melakukan upaya integrasi ini. Berdasarkan wawancara dengan guru mata pelajaran IPA di SMP 3 Kelas VIII, dalam proses pembelajaran guru masih memanfaatkan buku pegangan dengan menggunakan slide presentasi dan hal ini menjadikan materi yang membutuhkan alur proses berupa visualisasi sangat sulit dipahami oleh siswa. Kegiatan praktikum IPA sangat terbatas dalam hal alat peraga menyebabkan tujuan pembelajaran tidak maksimal.

Dari observasi tersebut dapat diperoleh permasalahan yang terjadi, diantaranya : (1) Siswa mendapat penjelasan dari guru di sekolah saja. Siswa menjadi bingung ketika mengulang pelajaran secara mandiri, dan setiap pertemuan berikutnya guru akan memberikan review materi dahulu kembali; (2) Siswa hanya mendapat penjelasan mengenai proses dan replika organ di sekolah, karena keterbatasan alat peraga di rumah; (3) Siswa mendapat penjelasan secara teks dan gambar. Kondisi demikian sangat berdampak pada hasil belajar dan motivasi belajar siswa, meskipun sarana telah mendukung untuk inovasi dalam teknologi pembelajaran. Salah satu jenis media yang dipilih adalah Multimedia pembelajaran berbasis Cross Platform (Handphone dan Laptop), yang di dalamnya menjelaskan tentang simulasi proses pendengaran dan sistem sonar pada makhluk hidup. semua siswa mempunyai Handphone Android dan Laptop, dan pihak sekolah mengizinkan alat tersebut untuk di bawa ke sekolah, hal ini mempermudah siswa memilih multimedia yang akan digunakan dalam proses belajara secara mandiri.

Multimedia cross platform yang sesuai kebutuhan dapat merangsang indera dan rasa ingin tahu para siswa secara langsung aktif dalam kegiatan belajar mengajar. Dari uraian di atas, upaya pengembangan media yang sesuai dengan karakteristik materi dan karakteristik pebelajar perlu dilakukan, sehingga multimedia hasil pengembangan tersebut dapat dijadikan sebagai penunjang dalam kegiatan pembelajaran IPA pada kelas VIII SMPN 3 Malang.

\section{METODE PENGEMBANGAN Model Pengembangan}

Model pengembangan yang digunakan dalam penelitian pengembangan ini adalah model William W. Lee \& Diana L. Owens. Dalam model pengembangan ini terdapat tahapan-tahapan yang dilakukan untuk mencapai hasil pengembangan produk yang diharapkan. Adapun tahapan-tahapan tersebut antara lain; (1) analisis (analysis), (2) desain (design), (3) pengembangan (development), penerapan (implementation), dan (5) evaluasi (evaluation). Adapun dalam pengembangan bahan ajar Grammar one berbasis mobile learning ini, pengembang membatasi tahapan tersebut hanya sampai pada tahap pengembangan (development).

Alasan pemilihan model pengembangan Lee \& Owens ini adalah: (1) model Lee \& Owens dirancang khusus untuk mengembangkan desain pembelajaran berbasis multimedia (2) alur pengembangan model Lee \& Owens ini sangat lengkap dan sistematik, mulai dari tahap analisis yang sangat komplek, desain, pengembangan dan penerapan, dan evaluasi, (3) dalam model Lee \& Owens terdapat komponen analisis yang sangat lengkap 
sehingga produk pengembangan akan menjadi optimal dan akurat.

\section{Prosedur Pengembangan}

Tahap tahap model pengembangan Lee \& Owens yang digunakan dalam penelitian pengembangan ini adalah analisis, desain, dan pengembangan.

\section{Analisis (Analysis)}

Tahap analisis dalam model Lee \& Owens dibagi menjadi dua jenis yaitu analisis kebutuhan dan analisis front-end. Analisis kebutuhan adalah cara sistematik untuk menentukan kesenjangan antara keadaan nyata saat ini dengan keadaan yang dinginkan dan menentukan prioritas tindakan yang akan dilakukan. Sedangkan analisis front-end merupakan teknik pengumpulan data yang digunakan untuk menjembatani kesenjangan yang ada antara kenyataan dan harapan untuk menyelesaikan permasalahan tersebut. Adapun tahapan dari analisis front-end antara lain adalah (1) analisis pebelajar, (2) analisis teknologi, (3) analisis situasi, (4) analisis tugas, (5) analisis kejadian penting, (6) analisis isu, (7) analisis tujuan, (8) analisis media, (9) analisis data yang masih tersedia, dan (10) analisis biaya.

\section{Desain (Design)}

Desain merupakan langkah kedua dari model Model pengembangan Lee Owen. Langkah-langkah yang dilakukan pengembang dalam tahap perencanaan desain adalah (1) menyusun jadwal pelaksanaan pengembangan (schedule), menyusun tim proyek (project team), (3) menentukan spesifikasi media (media specifications), (4) menyusun struktur pelajaran (lessons structure), dan (5) kontrol konfigurasi (configuration control).

\section{Pengembangan (Development)}

Tahap pengembangan merupakan tahap akhir dalam penelitian

pengembangan bahan ajar grammar one berbasis mobile learning ini. Adapun dalam tahap ini dilakukan dengan empat tahap yaitu: pra produksi, proses produksi, uji coba produk (quality review), dan implementasi (delivery).

\section{Uji Coba Produk}

Tujuan dari tahap ini adalah untuk mengukur kualitas dari produk. Produk pengembangan bahan ajar IPA berbasis cross platform yang dikembangkan dalam penelitian ini diharapkan memiliki tingkat kelayakan yang tinggi dalam pembelajaran. Untuk itu perlu dilakukan serangkaian uji coba produk yang dihasilkan sekaligus melakukan revisi berdasarkan uji coba tersebut. Uji coba dilaksanakan melalui beberapa tahap, yaitu: (1) review oleh ahli materi, Ahli materi dalam produk pengembangan ini adalah Drs. Nur Rochmat, beliau adalah tenaga pengajar mata pelajaran IPA di SMP Negeri 3 Malang, (2) review ahli media, Ahli media adalah Henry Prahendhiono, S.Si., M.Pd. selaku sebagai Dosen pada Program Studi Teknologi Pendidikan Fakultas Ilmu Pendidikan Universitas Negeri Malang, (3) review ahli desain. Ahli untuk desain dalam produk pengembangan grammar one adalah Eka Pramono Adi, S.IP, M.Si, selaku Dosen pada Program Studi Teknologi Pendidikan Fakultas Ilmu Pendidikan Universitas Negeri Malang, (4) uji coba perorangan. Uji coba perorangan dilakukan kepada 3 pebelajar SMP Negeri 3 Malang kelas VIII, (5) uji coba kelompok kecil. Uji coba kelompok kecil dilakukan kepada 6 pebelajar SMP Negeri 3 Malang kelas VIII, dan (6) uji coba kelompok besar. Uji coba lapangan dilakukan kepada 31 


\section{Analisis Data}

Teknik analisis data yang dipergunakan untuk mengolah data dari hasil validasi dari para ahli dan uji coba perorangan, kelompok kecil, dan lapangan pada pengembangan bahan ajar grammar one yaitu menggunakan analisis statistik deskriptif Rumus yang digunakan untuk analisis data adalah sebagai berikut. (Arikunto: 2006)

$P=\frac{\text { jumlah skor jawaban }}{n \times \text { bobot terting gi }} \times 100 \%$

Sedangkan Interpretasi hasil analisis untuk mengetahui tingkat criteria kelayakan adalah:

Tabel 1.1 Kriteria Kelayakan Media

\begin{tabular}{cll}
\hline Tingkat Pencapaian & Kualifikasi & Keterangan \\
\hline $81 \%-100 \%$ & Sangat Layak & Tidak perlu direvisi \\
$61 \%-80 \%$ & Layak & Tidak perlu direvisi \\
$41 \%-60 \%$ & Cukup Layak & Direvisi \\
$21 \%-40 \%$ & Kurang Layak & Direvisi \\
$0 \%-20 \%$ & Tidak Layak & Direvisi \\
\hline
\end{tabular}

(Riduwan, 2012)

Tabel. 1.2 Konversi Tingkat Keefektifan Produk

\begin{tabular}{ccccc}
\hline No & Rentangan & Angka & Nilai Huruf & Kualifikasi \\
\hline 1 & $91 \%-100 \%$ & 4 & A & Sangat Efektif \\
2 & $81 \%-90 \%$ & 3 & B & Efektif \\
3 & $71 \%-80 \%$ & 2 & C & Cukup Efektif \\
4 & $61 \%-70 \%$ & 1 & D & Kurang Efektif \\
5 & $<60 \%$ & 0 & E & Tidak Efektif \\
\hline
\end{tabular}

Diadaptasi dari Wiyono (2009: 53)

Tabel 3.6 Kriteria Motivasi Belajar Mahasiswa

\begin{tabular}{ll}
\hline Skor Persentase & Kriteria \\
\hline $76 \%-100 \%$ & Sangat Baik \\
$51 \%-75 \%$ & Baik \\
$26 \%-50 \%$ & Cukup \\
$0 \%-25 \%$ & Kurang \\
\hline (diadaptasi dari Ana, 2014) &
\end{tabular}


HASIL PENGEMBANGAN

\section{Hasil Validasi Ahli Materi}

Dari hasil persentase yang diperoleh dari ahli materi terkait dengan kelayakan produk yang dikembangkan, diperoleh tingkat persentase pada aplikasi dekstop 93,3\% dan mobile 94,6\%. Selanjutnya hasil tersebut dikonversi pada Tabel kriteria kelayakan, maka diperoleh hasil bahwa produk pengembangan bahan ajar IPA adalah sangat layak. Berdasarkan hasil validasi oleh ahli materi terdapat beberapa masukan antara lain materi lebih rinci, latihan soal kurang banyak dan kesesuaian gambar dan materi kurang tepat.

\section{Hasil Validasi Ahli Desain}

Dari hasil persentase yang diperoleh dari ahli desain terkait dengan kelayakan produk yang dikembangkan, diperoleh tingkat persentase aplikasi dekstop 85,3\% dan mobile $88 \%$. Selanjutnya hasil tersebut dikonversi pada Tabel kriteria kelayakan, maka diperoleh hasil bahwa produk pengembangan bahan ajar Indera Pendengaran dan Sistem Sonar Makhluk Hidup adalah sangat layak. Berdasarkan hasil validasi oleh ahli desain terdapat beberapa masukan/komentar dan saran, antara lain menambahkan tombol navigasi back, mengganti jenis teks dari comic sans ms menjadi times new roman.

\section{Hasil Validasi Ahli Media}

Dari hasil persentase yang diperoleh dari ahli media terkait dengan kelayakan produk yang dikembangkan, , diperoleh tingkat persentase aplikasi dekstop 97,3\% dan mobile 97,3\%. Selanjutnya hasil tersebut dikonversi pada Tabel kriteria kelayakan, maka diperoleh hasil bahwa produk pengembangan bahan ajar Indera Pendengaran dan Sistem Sonar Makhluk adalah sangat layak. Berdasarkan hasil validasi oleh ahli media terdapat beberapa masukan dan saran, antara lain perlu mempertimbangkan kemudahan dengan meletakkan file .apk dalam penyimpanan online.

\section{Uji Coba Perorangan}

Tahap uji coba perorangan dilakukan dilakukan kepada 3 pebelajar SMP Negeri 3 Malang kelas VIII.3. Dari hasil total persentase yang diperoleh dari uji coba perorangan terkait dengan kelayakan produk yang dikembangkan diperoleh tingkat persentase aplikasi desktop sebesar 84,6\%, dan pada aplikasi mobile sebesar 83,3\%. Selanjutnya hasil tersebut dikonversi pada Tabel kriteria kelayakan, maka diperoleh hasil bahwa produk pengembangan bahan ajar Indera Pendengaran dan Sistem Sonar Makhluk adalah sangat layak.

\section{Uji Coba Kelompok Kecil}

Tahap uji coba kelompok kecil dilakukan dilakukan kepada 9 pebelajar SMP Negeri 3 Malang kelas VIII.3. Dari hasil total persentase yang diperoleh dari uji coba kelompok kecil terkait dengan kelayakan produk yang dikembangkan diperoleh tingkat persentase aplikasi desktop sebesar 84,8\%, dan pada aplikasi mobile sebesar $83,5 \%$. Selanjutnya hasil tersebut dikonversi pada Tabel kriteria kelayakan, maka diperoleh hasil bahwa produk pengembangan bahan ajar Indera Pendengaran dan Sistem Sonar Makhluk adalah sangat layak.

\section{Uji Coba Kelompok Besar}

Tahap uji coba kelompok besar dilakukan dilakukan kepada 31 pebelajar SMP Negeri 3 Malang kelas VIII.3. Dari hasil total persentase yang diperoleh dari uji coba kelompok besar terkait dengan kelayakan produk yang dikembangkan diperoleh tingkat persentase aplikasi desktop sebesar 85\%, dan pada aplikasi mobile sebesar $85,5 \%$. Selanjutnya hasil tersebut dikonversi pada Tabel kriteria kelayakan, maka diperoleh hasil bahwa produk pengembangan bahan ajar Indera Pendengaran dan Sistem Sonar Makhluk adalah sangat layak.

\section{Uji Motivasi Perorangan}


Tahap uji motivasi perorangan dilakukan dilakukan kepada 3 pebelajar SMP Negeri 3 Malang kelas VIII.3. Dari hasil total persentase yang diperoleh dari uji motivasi perorangan terkait dengan kelayakan produk yang dikembangkan diperoleh tingkat persentase aplikasi desktop sebesar 86,6\% pada aplikasi mobile 87,3\%. Selanjutnya hasil tersebut dikonversi pada Tabel kriteria motivasi belajar siswa, maka diperoleh hasil bahwa produk pengembangan bahan ajar Indera Pendengaran dan Sistem Sonar Makhluk adalah sangat baik dalam memotivasi siswa untuk belajar.

\section{Uji Motivasi Kelompok Kecil}

Tahap uji motivasi kelompok kecil dilakukan dilakukan kepada 9 pebelajar SMP Negeri 3 Malang kelas VIII.3. Dari hasil total persentase yang diperoleh dari uji motivasi kelompok kecil terkait dengan kelayakan produk yang dikembangkan diperoleh tingkat persentase aplikasi desktop sebesar $83,1 \%$ pada aplikasi mobile 83,6\%. Selanjutnya hasil tersebut dikonversi pada Tabel kriteria motivasi belajar siswa, maka diperoleh hasil bahwa produk pengembangan bahan ajar Indera Pendengaran dan Sistem Sonar Makhluk adalah sangat baik dalam memotivasi siswa untuk belajar.

\section{Uji Motivasi Kelompok Besar}

Tahap uji motivasi perorangan dilakukan dilakukan kepada 31 pebelajar SMP Negeri 3 Malang kelas VIII.3. Dari hasil total persentase yang diperoleh dari uji motivasi perorangan terkait dengan kelayakan produk yang dikembangkan diperoleh tingkat persentase aplikasi desktop sebesar $84,7 \%$ pada aplikasi mobile $85,3 \%$. Selanjutnya hasil tersebut dikonversi pada Tabel kriteria motivasi belajar siswa, maka diperoleh hasil bahwa produk pengembangan bahan ajar Indera Pendengaran dan Sistem Sonar Makhluk adalah sangat baik dalam memotivasi siswa untuk belajar.

\section{Uji Coba Lapangan}

Tahap uji coba lapangan dilakukan dilakukan kepada 31 pebelajar SMP Negeri 3
Malang kelas VIII.3. Dari hasil total persentase yang diperoleh dari uji coba lapangan terkait dengan kelayakan produk yang dikembangkan diperoleh tingkat persentase $100 \%$. Selanjutnya hasil tersebut dikonversi pada Tabel kriteria efektivitas, maka diperoleh hasil bahwa produk pengembangan bahan ajar ajar Indera Pendengaran dan Sistem Sonar Makhluk adalah sangat efektif.

\section{KAJIAN PRODUK PENGEMBANGAN \\ 1. Konsep Desain}

Dalam mengembangkan produk multimedia pembelajaran, penulis memilih pokok bahasan Indera Pendengaran dan Sistem Sonar pada Makhluk Hidup karena termasuk ke dalam materi yang membutuhkan penjelasan secara visualisasi. Penulis mempertimbangkan kebutuhan dan ketersediaan teknologi yaitu komputer dan handphone yang semakin hari semakin bertambah penggunanya. Produk yang dikembangkan memiliki beberapa elemen yang mampu menambah ketertarikan dan kemudahan siswa dalam mempelajari materi. Elemen tersebut adalah adanya teks, gambar, audio, dan animasi yang mendukung materi. Berikut bagian - bagian dari multimedia antara lain:

\section{a. Splash Screen (cover)}

Menu opening (cover) merupakan menu pembuka dalam produk multimedia yang dikembangkan. Menu splash screen akan tampil dan langsung masuk ke menu utama secara otomatis.Pada halaman ini terdapat dua tombol yaitu tombol keluar yang berwarna merah dan tombol masuk yang berwarna hijau. Tombol masuk menuju ke halaman selanjutnya yaitu halaman menu utama.

b. Menu Utama

Pada menu utama produk multimedia media pembelajaran, terdapat beberapa bagian yaitu : (a) Tentang Aplikasi, (b) Tombol Keluar, (c) materi Indera Pengaran manusia, (d) mekanisme pendengaran manusia, (e) Sistem Sonar, dan (f) Latihan. 
1) Tentang Aplikasi

Pada Halaman ini berisi informasi mengenai Aplikasi yaitu Pembuat Aplikasi, Validator (Materi, Media, Desain), Dosen Pembimbing.

2) Tombol Keluar

Digunakan untuk keluar dari program / aplikasi.

\section{Sajian Materi}

Pada Menu ini terdapat 3 submenu diantaranya: (a) Anatomi Indera pendengaran, (b)Bunyi, dan (c) getaran. Pada sub menu Anatomi menjelaskan tentang bagian-bagian telinga manusia serta fungsinya, sedangkan pada submenu Bunyi menjelaskan tentang frekuensi bunyi, karakteristik bunyi (tinggi rendahnya bunyi, Nada, Desah, warna / kualitas bunyi, dan resonansi), dan terakhir adalah sub menu getaran, yaitu menjelaskan tentang getaran, gelombang mekanik, elektromegnetik, gelombang transversal, gelombang longitudinal.

a. Mekanisme pendengaran manusia

Pada tampilan ini terdapat animasi yang menjelaskan proses kerja telinga manusia mulai dari gelombang masuk ke dalam telinga yang selanjutnya ditangkap oleh daun telinga hingga diteruskan oleh saraf menuju ke otak.

\section{b. Sistem Sonar}

Pada menu sistem sonar menjelaskan tentang Sistem sonar, pemanfaatan sistem sonar pada kehidupan manusia diantaranya pada bidang kesehatan, dan untuk mengetahui kedalaman lautan.

c. Latihan

Pada halaman ini terdapat dua jenis latihan yaitu Multiple choice dan Short Essay. Pada tampilan ini, user mengerjakan soal dengan cara meng- klik pilihan jawaban yang tersedia pada tombol a,b,c,d, jika pilihan salah maka akan muncul tampilan "Jawaban anda SALAH, yang benar ...", jika jawaban anda benar maka akan muncul tampilan "Jawaban anda BENAR, yaitu...”, setelah mengerjakan 10 soal, maka akan muncul hasil tes yang berisi Nilai, jawaban benar dan salah.

\section{Kelebihan}

1) Dilengkapi dengan Animasi, ilustrasi gambar, audio dan video yang dapat membantu siswa memahami materi pembelajaran.

2) Aplikasi Dapat dijalankan di laptop dan handphone

3) File Installasi Aplikasi handphone dapat diunggah di Google Play Store, sehingga mudah dalam mengakses

4) Dilengkapi dengan petunjuk penggunaan, sehingga dapat membantu pengguna dalam memanfaatkan multimedia ini.

5) Dapat dijadikan sebagai sumber belajar selain buku paket.

\section{Kekurangan}

1) Kepingan $C D$ yang mudah rusak atau pecah.

2) Penggandaan $C D$ dan buku petunjuk yang mahal.

3) Butuh koneksi internet untuk mengunduh file di Google Play Store

4) Membutuhkan Handphone dengan sistem operasi Android

5) Membutuhkan waktu yang relatif lama jika akan memperbaharui materi pembelajaran karena harus menguasai software Adobe Flash.

\section{Saran Pemanfaatan}

a. Bagi Penulis

Dapat menghasilkan multimedia pembelajaran yang nantinya dapat dimanfaatkan oleh instansi pendidikan dan juga sebagai latihan aplikasi teori dari perkuliahan.

b. Bagi guru/calon guru

Saran pemanfaatan produk dari penulis yang berkaitan dengan multimedia sebagai berikut,

- Produk multimedia ini akan lebih baik manfaatnya apabila guru 
membaca petunjuk penggunaan terlebih dahulu.

- Guru juga harus aktif dalam proses pembelajaran agar materi dapat tersampaikan dengan baik. Hasil pengembangan ini dapat dijadikan referensi dalam pembelajaran IPA serta meningkatkan kreatifitas guru dalam mengembangkan pola pembelajaran IPA.

c. Bagi siswa

Dapat dijadikan sebagai salah satu sumber belajar yang dapat dimanfaatkan untuk memotifasi diri siswa dalam belajar. Siswa juga disarankan untuk mempelajari dengan baik materi Indera pendengaran dan sistem sonar pada makhluk hidup.

\section{KESIMPULAN DAN SARAN}

Multimedia ini hendaknya dikembangkan lebih baik oleh peneltianpenelitian yang lebih lanjut, sehingga dapat memberikan hasil yang lebih baik lagi. Mengkaji lebih dalam pada saat pemilihan materi dan pemilihan software yang digunakan. Akan lebih baik lagi jika pengembangan selanjutnya tidak hanya menyediakan satu mata pelajaran tetapi terdapat berbagai mata pelajaran yang dapat diikuti oleh siswa sehingga tidak hanya mata pelajaran IPA bab Indera Pendengaran dan Sistem Sonar pada Makhluk Hidup.

\section{DAFTAR RUJUKAN}

Ana, R. F. R. 2014. Peningkatan Motivasi, Aktivitas, dan Hasil Belajar IPS dengan Model Kooperatif Think Pair Share (TPS) Studi Kelas IV SDA Kamulan 01 Kecamatan Talun Kab. Blitas. Tesis tidak diterbitkan. Malang: Program Pascasarjana Universitas Negeri Malang.

Ariani, N \& Haryanto, D. 2010. Pembelajaran Multimedia di Sekolah: Pedoman Pembelajaran Inspiratif, Konstruktif dan prospektif. Jakarta: Prestasi Pustakarya.

Arikunto, S. 2010, Prosedur Penelitian: Suatu Pendekatan Praktek. Jakarta: PT. Rineka Cipta

Daryanto. 2010. Media Pembelajaran : Peranannya sangat penting dalam mencapai tujuan pembelajaran. Yogyakarta : Gava Media

Lee, W \& Owens, D, L. 2004. Multimedia Based Instructional Design, Second Edition. United States of America; John Wiley \& Sonc, Inc.

Mayer, R. E. 2009. Multimedia Learning. Yogyakarta : Pustaka Belajar.

Riduwan, M. 2012. Dasar-Dasar Statistika. Bandung: Alfabeta 